\title{
Examining Trait Anger Among Male and Female College Students
}

\author{
Priyanka Guleria
}

\begin{abstract}
The current research aims to study trait anger among male and female college students. The current research participants included a total of 80 (40 male and 40 Female). Age range of both the student groups ranged from $20-22$ years. Mean age of male and female students was 21.05 and 20.08 respectively. All of these students had and urban and semi - urban idle class socioeconomic background and were unmarried. All the students were studying in the third year of B. Sc (Bachelor of Science) course in Degree College Hamirpur, Himachal Pradesh, India. The data was collected through the "Personal Information Form", "State Trait Anger Expression Index (STAXI)". The t test was used to compare the means of the two groups. The results showed that there was no significant difference between these two groups (Male and Female) with regards to trait anger.
\end{abstract}

Keywords: College Male and Female students, Trait Anger.

\section{INTRODUCTION}

Trait anger is described as a dispositional characteristic where one experiences frequent anger, with varying intensity (e.g., mild irritability, intense rage) and is often accompanied by related negative emotions such as envy, resentment, hate \& disgust (Buss, A. H. 1961; Siegman, A. W., \& Smith, T. W., 1994). College life is composed of different stressful situations. Several investigators have attempted to study young adults particularly college students in terms of their stresses. The findings of these studies in general revealed students are likely to encounter the problems related to academics, relationships or work while some college students appear to adapt well to stressful situations. Some others may become vulnerable to similar situations (Baldwin, D. R., Chambliss, L. N., \& Towler, K., 2003). Anger, aggression and hostility have adverse impacts on family, work and society. Students and veterans often consider anger their most salient problem (Blum MD, Kelly EM, Meyer M, Carlson CR, Hodson W, 1984). The negative impact of anger and hostility on emotional well - being has been demonstrated in numerous studies (Carmody TP, Crossen JR, Wiens AN, 1989; Mook, Van der Ploeg, H M, 1990). Researches have linked anger and hostility to cardiovascular disorders (Chesney, M. A. \& Roseman, R. H., 1965) Earlier, Diamond EL (1982) presented a clinical review of literature pertaining to the role of anger and hostility in essential hypertension.

Manuscript received on September 09, 2021.

Revised Manuscript received on September 11, 2021.

Manuscript published on September 30, 2021.

* Correspondence Author

Priyanka Guleria, Department of Psychology, SAM Global University, Bhopal (M.P), India. Email: 83.priyanka.thakur@gmail.com

(C) The Authors. Published by Blue Eyes Intelligence Engineering and Sciences Publication (BEIESP). This is an open access article under the CC BY-NC-ND license (http://creativecommons.org/licenses/by-nc-nd/4.0/)
Beside other conclusions that showed that anger and hostility appeared to play an important role in the development of hypertension. Demborski, McDougall, Williams and Blumenthal (1985) found that high ratings of anger-in were significantly and positively associated with severity of coronary atherosclerosis. Van der Ploeg, $\mathrm{H}$ M et al. (1985) examined the relationship in 35 female and 69 male college students in Netherlands. Results indicate that hypertensive's avoid showing anger or suppress anger.

Smith, T W. (1992) found anger, hostility and health to be related. Bilge F. and Saltuk S. (2007) compared college students subjective well - being, trait anger and trait anxiety according to their style of humors, to assess these variables. Humors styles questionnaire subjective well-being scale, Trait Anger scale, Trait Anxiety scale were administered to 759 volunteering students, 477 girls and 282 boys. The means of subjective well - being, trait anger and anxiety scores of the higher and lower groups of $27 \%$ categorized according to the scores received from the affiliative, self-enhancing, aggressive and self-defeating humor styles were higher whereas their trait anger and anxiety scores were lower. Trait anger scores of students using aggressive humor style were higher while their subjective well - being scores were lower, trait anxiety of students with self - defeating humor style were also higher.

In a recent study Forgays, D. K., Richards, J., Forgays, D.G., \& Sujan, S. (1999) identified significant relation between illness and anger; most studies focus selectively on one anger domain: either the affective, attitudinal or behavioral component. In this study, researchers firstly related all three components of the AHA! (Anger, Hostility and Aggressive behavior) syndrome to somatic complaint reports in male and female college students drawn from three countries. In subsequent analyses, researchers related multidimensional characteristics of anger to illness in those young adults who regularly use tobacco and alcohol. In both the total sample and the substance user analyses, researchers found that the anger illness profile varied as a function of gender. Earlier, Grunbaum, JA et al. (1997) examined that association between anger, hostility, physiologic and behavioral risk factors for coronary heart disease (CHD) in college students. As early as 1950s, Cobb S. (1959) examined the emotion of anger, aggression and hostility has been widely observed among college male - female students. Anger as a significant factor which elevates migraine and tension type headaches among college students. Cevik, G.B. (2017) studied that anger out and trait anger dimensions of satisfaction with life did not differ on accommodation (home, dormitory). 
On the other hand, the group effect of the anger-in scores were found to be on significant levels. As such, anger-in scores of individuals living in the dormitories were found to be higher than those of individuals living in homes. According to Emily A. Munoz (2005) overall boy's and girl's anger were similar in most aspects in undergraduate students' then girls. Also, female students' anger was more commonly directed towards a boyfriend or was regarding family. Male students also had issues with girlfriends but discussed that type of issue less than women. Majority of the studies demonstrated that subjective well - being of students who were using affiliative and self - enhancing humor styles were higher whereas their trait anger and anxiety scores were lower. Anger, aggression and hostility have adverse impact on family, work setting, students and society. Reviews indicated that anger is an important negative emotion in well -being; however, this variable has not been explored

\section{HYPOTHESIS}

Hypothesis stated that female students will report significantly higher trait anger than male students.

\section{METHODOLOGY}

The present study considered 40 male and 40 female college students from Government Degree College, Hamirpur, Himachal Pradesh, India. Age range of both the student groups ranged from 20-22 years. Mean age of male and female students was 21.05 and 20.08 respectively. All these participants had an urban and semi urban middle class socio-economic background and were unmarried.

\section{RESEARCH TOOLS}

Hindi version of State - Trait Anger Expression Inventory (STAXI) - The State Trait Anger Expression Inventory (STAXI) developed by Spielberger and his associates (Spielberger, 1988; Jacobs, Russel and Crane 1983; Spielberger et.al. 1985) provides concise measure of the experience and expression of anger. Anger is conceptualized as having two major components state and trait. In the present study, only ten items of trait-anger will be used which will measure individual differences in the disposition to experiment anger. The alpha reliability of particular trait anger is .89 (female) and .96 (male). The Hindi STAXI can be used for research in India and subsequent comparison of the findings with those obtained on English speaking population.

\section{DATA COLLECTION}

Hindi version of State - Trait Anger Expression Inventory was administered to the subjects individually. The scale was administered according to standard instructions. more information on proofreading, spelling and grammar. A cover sheet was used to collect information regarding demographic characteristics of the subjects. This included gender, age, income, religion, type of family, marital status and residential background. Subjects were assured that their results would be kept confidential and would be used only for research purposes. stories. Male students told shorter accounts of their anger adequately across population especially among students.

\section{SCORING OF STAXI SCALE}

T-Anger scale comprised 10 items which measure individual differences in the disposition to experience anger. The scores on each item corresponded to the number encircled on the test form. Thus, item score varies from 1 to 4 . The score on T-Anger is computed by summing the column scores. The range of possible score for $\mathrm{T}$-Anger varies from a minimum of 10 to the maximum of 40. Subjects high in T-Anger frequently experienced angry feelings and often felt they were unfairly treated.

\section{STATISTICASL ANALYSIS}

Scores were subjected to "T" test to compare the males and females with regard to Trait Anger. Mean score, Standard Deviation and T-value for male and female college students is shown in the table below.

\section{Trait Anger among College Male \& Female Students}

\begin{tabular}{|l|l|l|l|}
\hline Variable & $\begin{array}{l}\text { Female College } \\
\text { Students }\end{array}$ & $\begin{array}{l}\text { Male College } \\
\text { Students }\end{array}$ & T-Value \\
\hline Trait Anger & $\begin{array}{l}\mathrm{M}=20.2750 \\
\mathrm{SD}=4.7931\end{array}$ & $\begin{array}{l}\mathrm{M}=18.87 \\
\mathrm{SD}=2.73\end{array}$ & 1.61 \\
\hline
\end{tabular}

\section{CONCLUSION}

The -statistic measures how many standard errors the coefficient is away from zero. Generally, any t-value greater than +2 or less than -2 is acceptable. "The higher the t-value, the greater the confidence we have in the coefficient as a predictor. Low t-values are indications of low reliability of the predictive power of that coefficient." https://www.allbusiness.com/barrons_dictionary/dictionary-t -value-4942040-1.html

Since the t-value in the present study is within -2 and +2 we can conclude that there was no significant difference between the two groups (Male and Female College students) with regards to trait anger. abbreviate "Table." Tables are numbered with Roman numerals. Include a note with your final paper .

\section{REFERENCES}

1. Buss, A. H. (1961). The psychology of aggression. New York: Wiley.

2. Siegman, A. W., \& Smith, T. W. (Eds.). (1994). Anger, hostility, and the heart. Hillsdale, NJ: Erlbaum.

3. Baldwin, D. R., Chambliss, L. N., \& Towler, K. (2003). Optimism and stress: An African-American college student perspective. College Student Journal, 37(2), 276-285.

4. Blum MD, Kelly EM, Meyer M, Carlson CR, Hodson WL. An assessment of the treatment needs of Vietnam-era veterans. Hosp Community Psychiatry. 1984 Jul;35(7):691-6. Doi: 10.1176/ps.35.7.691. PMID: 6745875.

5. Carmody TP, Crossen JR, Wiens AN. Hostility as a health risk factor: relationships with neuroticism, Type A behavior, attentional focus, and interpersonal style. J Clin Psychol. 1989 Sep;45(5):754-62. Doi: 10.1002/1097-4679(198909)45:5<754::aid-jclp2270450510>3.0.co;2 -c. PMID: 2808731.

6. Chesney, M. A. , \& Roseman, R. H. (Eds.). (1985). Anger and hostility in cardiovascular and behavioral disorders, New York: Hemisphere, McGraw-Hill.

7. Diamond EL. The role of anger and hostility in essential hypertension and coronary heart disease. Psychol Bull. 1982 Sep;92(2):410-33. PMID: 7146235. 
8. Dembroski, T M et al. "Components of Type A, hostility, and anger-in: relationship to angiographic findings." Psychosomatic $\begin{array}{llll}\text { medicine } & \text { vol. } & 47,3 & \text { (1985): }\end{array}$ doi:10.1097/00006842-198505000-00001

9. Van der Ploeg, H M et al. "The role of anger in hypertension." Psychotherapy and psychosomatics vol. 43,4 (1985): 186-93. doi:10.1159/000287878

10. Smith, T W. "Hostility and health: current status of a psychosomatic hypothesis." Health psychology: official journal of the Division of Health Psychology, American Psychological Association vol. 11,3 (1992): 139-50. doi:10.1037//0278-6133.11.3.139

11. Filiz Bilge and Sinem Saltuk. "Humor styles, Subjective Well Being, Trait Anger and Anxiety among University Students in Turkey.' World Applied Sciences Journal 2 (5), (2007): 464-469. IDOSI Publications.

12. Forgays, D. K., Richards, J., Forgays, D.G., \& Sujan, S. (1999). “An examination of the AHA! -illness relationship in older adolescent male and female students from three countries." International Journal of Behavioral Medicine, 6, 64-77.

13. Grunbaum, J A et al. "The association between anger and hostility and risk factors for coronary heart disease in children and adolescents: a review." Annals of behavioral medicine: a publication of the Society of Behavioral Medicine vol. 19,2 (1997): 179-89. doi:10.1007/BF02883335

14. Cobb, S (1959). Coronary Heart Diseases Statistics. London: British Health Foundation.

15. Çevik, Gülsen Büyüksahin. "Examining University Students' Anger and Satisfaction with Life" (2017) Journal of Education and Practice, v8 n7, 187-195.

16. Munoz, Emily A., "Gender Variation in Anger: A Study of Anger in Undergraduate Students" (2005). Chancellor's Honors Program Projects. https://trace.tennessee.edu/utk_chanhonoproj/895

\section{AUTHORS PROFILE}

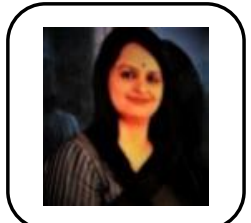

Priyanka Guleria is a research scholar in the Department of Psychology in SAM Global University, Bhopal, Madhya Pradesh, India. She holds an M. Phil degree in Psychology from Himachal Pradesh University, Shimla, a degree in M.A Psychology from HNB Garhwal University, Srinagar, M.A. in Education from Periyar University Salem and B.A from Himachal Pradesh University, Shimla. She is also a trained Psychologist specializing in Guidance \& Counselling with a PG Diploma in Guidance \& Counselling from Himachal Pradesh University. She is lifetime member of Counsellors Council of India and is a registered counsellor with National Career Service.

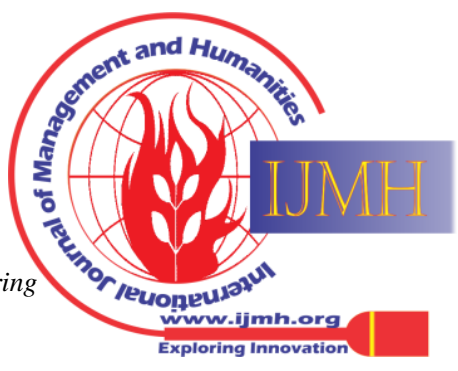

